\title{
The Influence of Accounting Information Quality on Financial Performance of Islamic Microfinance (BMT) (Case Study on Islamic Microfinance (Baitulmal Wattamwil -BMT) in Pontianak City)
}

\author{
Dr. Muhammad Syaifullah
}

Lecturer of Faculty of Sharia and Islamic Economics, IAIN Pontianak, Indonesia

\begin{abstract}
This study aims to mengetehaui whether there is influence of accounting quality of information on the performance of BMT in Pontianak City.This research is a descriptive research using quantitative approach, while data analysis technique using multiple regression model. The total population of this study amounted to 14 BMTs located in Pontianak City, from 14 distributed questionnaires who returned the quizener amounted to 8 BMT. This study examines all the existing population and the respondents are the 8 leaders of BMT in Pontianak City.This study was conducted in 2010.From the research result can be proved that there is Multiple Correlation Value (R) between variables $X_{1}, X_{2}, X_{3}, X_{4}$ and $X_{5}$ to $Y$ of 0.870, meaning: Quality Accounting information simultaneously have a strong and positive influence to financial performance. The termination coefficient (R2) of 0.756 means: the variance of the financial performance of 0.756 or $75.60 \%$ is explained or influenced by the quality of accounting information while the rest of $24.40 \%$ is influenced by other variables not found in this study.
\end{abstract}

Keywords: Quality of Accounting Information and Financial Performance.

\section{Introduction}

The crisis that began with the onset of the monetary crisis in July 1997 to the present day, is a very valuable lesson for mistakes in managing the economy. The lack of transparent economic management tendency, lack of creating the participation of the people, has created imbalance and injustice in the control of economic assets. In the end the national assets are only controlled by a small group of people, while the largest part of the people is on the poverty line.

Data from the Bureau of Statistics BPS in 2001 showed that of the total number of business units reached 40.137 million units of business, which classified large businesses only 40,000 units or only about $1 \%$. Meanwhile, small-scale business and home industry reached 40.137 million units or about 99\% (Yasni, 2003: 44). Of the large number of businesses it was able to control the market share of $70 \%$ to $80 \%$. While the big and medium only controlled the remaining $20 \%$. In terms of employment, the big business only absorbed about $12 \%$, the remaining $88 \%$ was absorbed by the small and medium business sector (Halwani, 1999: 44-45).

From these facts, then to all parties, especially the government, need to pay more attention to the empowerment of small and medium business sector. One form is to create a funding agency that can be easily accessed by small businesses. Besides, there is a growing awareness that economic practices including financial institutions have been far from the ethical values of society, as Fredrick Post (Muhmudi, 2001: 395) not only emphasizes high financial performance, but also ethical performance. Various financial institutions and credit with the interest system, is considered to be one cause of economic damage and contrary to Islam.
A suitable form to meet these demands is Baitulmal Wattamwil (BMT).According to Aziz in Abdul Majid (2000: 182) Baitulmall Wattamwill is a "people's economic enterprise that can and is able to serve small-bottom enterprise customers based on profit-sharing and buying and selling systems by utilizing the potential of collateral in their own environment".

Unfortunately the level of awareness and support the community does not necessarily smooth the development of BMT. As in the city of Pontianak, which there are only about 12 BMT that still operate? BMT data in Pontianak City can be seen in table 1.1 .

Table 1.1: List of BMTs in Pontianak City

\begin{tabular}{|c|c|}
\hline 1. & BMT Mujahidin \\
\hline 2. & BMT Al-Falah \\
\hline 3. & BMT Aisyiyah \\
\hline 4. & BMT Nurul Jannah \\
\hline 5. & BMT Insan Cita \\
\hline 6. & LKMS Borneo \\
\hline 7. & KOPERMAS Borneo Sejahtera \\
\hline 8. & BMT Ikhwanul Mukminin \\
\hline 9. & BJKS Kalbar Madani \\
\hline 10. & BMT Basmalah \\
\hline 11. & BMT Al-Ikhlas \\
\hline 12. & BMT Al-Asyraf \\
\hline 13. & BMT Mitra Sejahtera \\
\hline 14. & Of 2009 \\
\hline
\end{tabular}

Source: Processed Data of 2009

Obstacles in the face of BMT today can be categorized into two types, namely internal constraints and external constraints. Internal constraints include weak human resources and capital. While the constraints ektern include not clear the legal status of BMT and public understanding

Volume 6 Issue 12, December 2017 


\section{International Journal of Science and Research (IJSR) \\ ISSN (Online): 2319-7064}

Index Copernicus Value (2016): 79.57 | Impact Factor (2015): 6.391

about the implementation of sharia economy is not adequate. The emergence of various institutions of this sharia economy, requires accounting information that is also characterized sharia, which is subject to the provisions of sharia, both in concept maupu practice. The need for shariah accounting to call for sharia economic development, which in some ways is different from other economic systems.

Accounting in BMT is none other than accounting applied on the basis of business practices and transactions that develop on BMT. The existence of BMT was born from the application of Islamic Economic System which has been developed before. While Islamic Economic System is a form of economic system that mengawuh to Islamic Law (sharia), so by using the flow of thinking above and see the prevailing practices in BMT and Sharia Banking, then in this study used the term Sharia Accounting to assert accounting in applied in BMT.

In the development of sharia accounting today, based on the main sources of the Qur'an and Sunnah, which is described in a shariah accounting standard is Accounting and Auditing Standards for Islamic Financial (AASIFI) which became the official reference especially for Islamic financial institutions and apply international scale. Such standards by sharia accounting experts are considered to be the first syariah financial accounting standards to be reference material both for the purposes of practice and the basis for further development of Islamic accounting. Therefore, this study refers to Islamic financial accounting standards.

In Indonesia, accounting standards for sharia banks are Statements of Financial Accounting Standards (PSAK) No. 59 as of 1 July 2009. While there are many similarities of the above standards with conventional banking accounting, it does not invalidate the accounting of sharia law. So to a certain extent sharia accounting mengguankan results of conventional accounting development, acts contrary Shari'ah (Sofyan, 2001: 411).Currently, some Shariah compliant standards and accounting guidelines used by Islamic financial institutions are the Accounting and Auditing Standards and Auditing Organization for Islamic Institution (AAOIF) in Bahrain, Statement of Financial Accounting Standards (PSAK) No. 59, on Accounting for Sharia Banking. Issued by the Indonesian Accounting Association (IAI) and Accounting Guidelines for Sharia Banking (PAPSI) from Bank Indonesia. Currently BMTs are different from legal entities are cooperatives, so in terms of accounting there are things tertedu based on PSAK No. 27 on "Accounting of the Republic".

The existence of good accounting information is an effective tool for BMT management to direct and control the running of the company. Hines (1989: 11) reveals that the financial statements are very big role in showing the company eksintensi. Goodman (De-Alwis, 2001) suggests that the use of good accounting information will be related to firm performance. To measure the financial performance of BMT this study uses the ratios set Pinbuk, which specifically assess the financial performance of BMT.For BMT management as internal user, financial accounting information besides as an instrument of accountability to the owner (member) in member meeting, more important is as tool of performance evaluation, monitoring tool, source of work program preparation and planning. External party users use this financial accounting information as a basis to assess the performance of managers, credit provision from financial institutions, payment of zakat, infaq, and shadaqoh sera other aids. With good quality financial accounting information, it will ultimately provide important inputs for management and foster greater trust to BMTs. Then the condition will determine the achievement of financial performance diharpakan.

\section{Literature Review}

\subsection{Quality of Accounting Information}

The financial statements as a form of financial accounting information are understood as the media used by managers and parties concerned with the company related to the financial condition at certain period. Therefore this accounting information will serve as the basis for decision making, then the information must be qualified. The quality of a financial accounting information refers to the ability of the information is effective in decision making. Effective accounting information should refer to the existing standard of financial accounting information quality characteristics from the Statement of Financial Accounting Concept No.2 of the FASB. Especially for sharia financial institutions have been set in the AASIFI of AAOIFI.AASIFI Statement Number 2, as a reference of sharia accounting, describes the special characteristics for information useful for decision making, namely:

1) Relevance

Relevance refers to a strong relationship between accounting information and the purpose of making this information. An information is of relevant quality if the information has the ability to influence a decision to be taken and assist usage to make predictions about past, present, and future results of events, or which confirm previous expectations.

2) Reliability

Reliability means that based on all special circumstances surrounding a particular transaction or event, the method chosen to measure and or disclose the effectiveness of producing information reflects the substance of the event or transaction.

3) Comparability

The Company shall be consistent in the application of its measurement method and disclosure from one period to the next.

4) Consistency

Companies must be consistent in the application of measurement methods and their disclosure from one period to another.

5) Understandability

\subsection{Financial Performance}

Financial performance is the result achieved by the company for various activities undertaken in utilizing available financial resources. According to Cooper and Ijiri (1984: 378 ) the performance is "general term to part of the conduct or activities of an organization a priod of time". The essence of the above understanding is, firstly the terminology of

\section{Volume 6 Issue 12, December 2017}




\section{International Journal of Science and Research (IJSR) \\ ISSN (Online): 2319-7064}

Index Copernicus Value (2016): 79.57 | Impact Factor (2015): 6.391

performance to pay attention to the terminology of a general nature so that if not given clear limits in its application leads to a qualitative measure. The second has a subjective risk in its measurement and judgment. Third time span is crucial in applying performance. Financial performance is one of the valuation of company's financial condition which can be done based on company's financial ratio analysis. Suad Husnan (1996: 200) suggests that

"To assess the perception and financial condition of a company, a financial analyst requires a certain size. Commonly used sizes are ratios and indices that show the relationship between two financial data. Analysts and rational-sharing interpretations will provide a better understanding of the perceptions and financial conditions than those that merely reveal financial data ".

The financial condition of a company can be understood with a benchmark that is usually in use, namely financial ratios. However, using financial ratios will only know the magnitude of the ratio figures only. Therefore it is necessary to interpret the numbers of these ratios as well as to choose the kind of ratios that fit the purpose of the analysis (Van Horne, 2000: 349).

\subsection{Baitulmal Wattamwil (BMT)}

Baitulmal is a financial institution whose activities are managing non-profit (social) funds. Source of funds

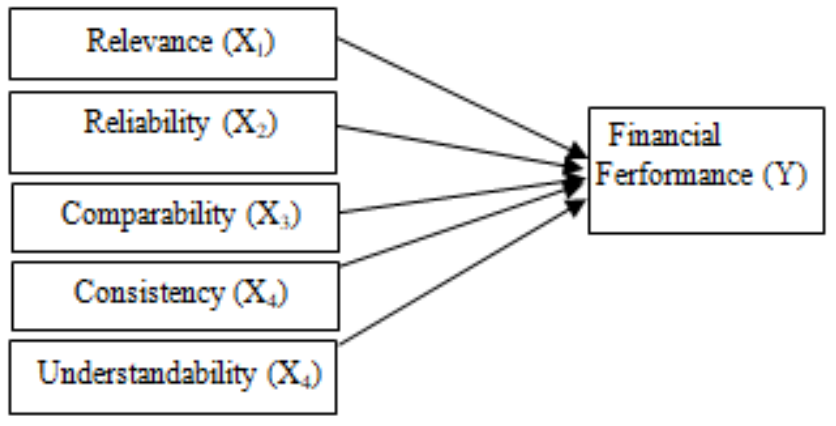

Figure 1: The Theoretical Framework Model

Hypothesis: There is influence between the quality of accounting information consisting of relevance, reliability, can be compared, consistency and can be understood to the financial performance of BMT in Pontianak City.

\section{Research Methods}

\subsection{Research Approach}

This form of research is an associative type of research, ie research that aims to determine the relationship of two or more variables, which serves to explain, predict and control a symptom (Sugiyono, 2002: 11). Data Collection Method, conducted through several ways, namely: Questionnaire, Direct Observation, and Documentary Studies. The population of this research is BMT-BMT located in Pontianak City which amounts to 14 BMT. The technique of determining the respondents is done by census to the entire population that includes 14 leaders on the BMT, so in this study did not use the sample. obtained from zakat, infaq, and alms or other halal sources. Then the funds are distributed to mustahik who is entitled or for good. While baituttanwil is a financial institution whose activities are collecting and channeling public funds and is profit motive. BMT also performs activities in the real sector, so BMT in its activities carry out three types of activities, namely:

1) Financial services in the form of fund raising and distribution of public funds.

2) Social, in the form of zalcat management, infaq, and alms.

3) Real sector, investment investment in real sector.

According to Aziz in Abdul Majid et al (2000: 182) Baitulmal Wattanwil is a populist economic business institutions that are able to serve small business customers based on profit-sharing system and trading by utilizing the potential of collateral in their own environment ". Baitulmal Wattamwil (BMT) is a community-based economic enterprise that can and is able to serve small-bottom enterprise customers based on profit-sharing system and selling by utilizing the potential of guarantee in their own environment (Aziz in Abdul Majid et al., 2000: 182). Furthermore A. Djazuli and Yadi Yanwari (2002: 183), baitulmal wattamwil is an informal non-banking sharia economic or financial institution. Informal in the sense that baitulmal wattamwil founded by a group of community selfhelp (KSM) is different from banking financial institutions and other formal financial institutions.

Variable The research consists of independent variable is the quality of sharia financial accounting information (varibel $\mathrm{X})$ based on the definition formulated by AAOIFI Statement No.2 as follows: a) Relevance, an information has relavan quality if the information has the ability to influence the decision to be taken; b) Reliability, quality of information that ensures that information is free from misinterpretation or bias; c) Can be compared, the quality of information that allows users to identify the similarities and differences between the two economic symptoms; d) Consistency, conformity of a period to the next period without any change of policy concerning accounting methods, techniques and procedures; and e) Can be understood, the information that allows users of accounting information can understand the meaning and maksa accounting information.

The dependent variable in this research is Financial Performance of BMT, that is financial achievement achieved by 9 BMT, in a period of activity measured by financial ratio. The operational definitions for BMT's financial performance applicable to BMTs include the following categories: a) Capital structure; b) Productive assets; c) Liquidity; d) Efficiency; e) Profitability. Data Analysis Technique that is 1) Relevance Picture of BMT Financial Report in Pontianak City, to know picture Relevansi BMT Financial Statement in Pontianak City, conducted by analyzing data obtained by spreading the questionnaire to BMT in Pontianak City which made sample, that is as many as 8 respondents, to be more informative and easy to understand, then the data in the analysis using descriptive statistics; 2) Test Statistics, data analysis tools used, namely multiple regression to test the effect of quality financial accounting information inividu and together to the financial

\section{Volume 6 Issue 12, December 2017}




\section{International Journal of Science and Research (IJSR) \\ ISSN (Online): 2319-7064}

Index Copernicus Value (2016): 79.57 | Impact Factor (2015): 6.391

performance of BMT in Pontianak City; 3) Hypothesis Testing is a) Testing individual influence, to test the influence of each individual aspects of quality financial information that includes: relavansi, reliability, comparable, consistency, and can be understood with financial performance done by using $\mathrm{T}$ test; $\mathrm{b}$ ) Tests of influence together. To examine the mutual influence of financial information quality aspects which include: relevance, reliability, comparability, consistency, and can be understood with financial performance, performed by $\mathrm{F}$ test; d) The coefficient terminated R2. To find out how much variance (diversity) financial performance that can be explained or influenced by the quality of accounting information and how much influence of other variables that are not contained in this study that affect the financial performance of BMT.

\section{Analysis And Discussion}

\subsection{Regression Analysis}

Influence of relevance of financial statements, reliability of financial statements, financial statements that can be compared, consistency of financial statements and financial statements that can be understood to the financial performance of BMT in Pontianak. In analyzing and explaining the influence of financial report report relevance, reliability of financial statements, financial statements that can compare the consistency of financial statements and financial statements that can be understood to the financial performance of BMT in Pontianak. Regression analysis is a statistic that aims to model the relationship between independent variables with dependent variables.

Test the influence simultaneously between the relevance of financial statements, financial statement keadalan, financial statements that can be compared, consistency of financial statements and financial statements that can be understood to the financial performance of BMT in the city of Pontianak. To know the influence of independent variable individually to depeneden variable based on coeficien from SPSS 16.00 calculation.

4.1.1 Test Effect simultaneously between the relevance of financial statements, the reliability of financial statements, financial statements that can be compared, the consistency of financial statements and financial statements that can be understood to the financial performance of BMT in Pontianak.

Based on the summary table of multiple linear regression test using SPSS 16.00 software obtained:

a) Multiple (R) correlation values between variables $X_{1}$, $\mathrm{X}_{2}, \mathrm{X}_{3}, \mathrm{X}_{4}$, and $\mathrm{X}_{5}$ to $\mathrm{Y}$ are 0.870 , artinye: relevance of financial statements, reliability of financial statements, comparable financial statements. Consistency of financial statements and financial reports that can be understood simultaneously have a strong and positive relationship to the financial performance of BMT in Pontianak City.

b) The termination coefficient (R2) of 0.756 means that the variation (diversity) of BMT's financial performance in Pontianak is 0.756 or $75.60 \%$ explained or influenced by the relevance of the financial statements, the reliability of the financial statements, the comparable financial statements, the consistency of financial statements and financial statements that can be understood while the rest of $24.40 \%$ influenced by other variables that are not contained in this study.

c) The value of $\mathrm{F}$ in the Anova table used to find out whether the variance of the value of the independent variable can influence simultaneously to the variance of the value of the dependent variable. To test whether the proposed hypothesis is accepted or rejected is done by:

Comparing Fcount with Ftable with based on degrees of freedom $(\mathrm{dk})$ of numerator $=5$ and degrees of freedom denominator $\mathrm{dk}=\mathrm{nk}-1$ ( $\mathrm{n}=$ number of sample members, $\mathrm{k}=$ number of independent variables), provided that $F$ count $>F$ table, the hypothesis zero (Ho) in rejection. Thus obtained degrees of freedom of 8-5-1 $=2$, with the degree of error $(\alpha)$ $=0.05$ or $5 \%$ by using the test one-right (one-tilet test) in obtained $F$ table of 19.33. After $F$ arithmetic (Fh) in consultation with Ftable (Ft) it can be known that Fhount is greater than Ftable $(1.243<19.33)$, so also with a significance greater than 0.05 , the null hypothesis $(\mathrm{Ho})$ is accepted, meaning the relevance of financial statements, relevance of financial statements, reliability of financial statements, comparable financial statements, consistency of financial statements and financial statements that can be understood not affect simultaneously to the financial performance of BMT in Pontianak City.

4.1.2 Test Effect partially between the relevance of financial statements, the reliability of financial statements, financial statements that can be compared, the consistency of financial statements and financial statements that can be understood to the financial performance of BMT in Pontianak City.

To know the power of influence of independent variable to dependent variable based on table coefficient of SPSS 16.00 calculation. From the research results obtained $\mathrm{T}$ value (Ttest) as follows:

- The value of $\mathrm{T}$ arithmetic for $\mathrm{X}_{1}$ is 2,064 with the significance of $0.046(1.780<3.18)$ the null hypothesis is accepted, meaning the relevance of the financial statements has no significant effect on the financial performance of BMT in Pontianak City.

- The value of $\mathrm{T}$ arithmetic for $\mathrm{X}_{2}$ is 2.064 with significance of $0.046(-2.046<3.18)$, the null hypothesis is accepted, meaning that the reliability of the financial statements does not have an individual effect on the financial performance of BMT in Pontianak.

- Thitung value for $\mathrm{X}_{3}$ of 2,064 with significance of 0.046 (0.424 <3.18) null hypothesis is accepted means that the financial statements that can be compared individually do not have a significant effect on the financial performance of BMT in Pontianak City.

- Thitung value for $\mathrm{X}_{4}$ of 2.064 with significance of 0.046 ($0.830<3.18)$ the accepted null hypothesis means that the consistency of individual financial statements has no significant effect on the financial performance of BMT in Pontianak City.

- Thitung value for $\mathrm{X}_{5}$ is 2,064 with significance to performance of BMT financial report in Pontianak City.

\section{Volume 6 Issue 12, December 2017}




\section{International Journal of Science and Research (IJSR) \\ ISSN (Online): 2319-7064}

Index Copernicus Value (2016): 79.57 | Impact Factor (2015): 6.391

Based on the value of Thitung can also know the variable that has the most dominant influence on the financial performance of BMT in Pontianak.Variabel which has dominant influence is the financial statements that can be understood, because based on the regression analysis obtained the highest Thitung value when compared with the variable others, amounting to 1,098 .

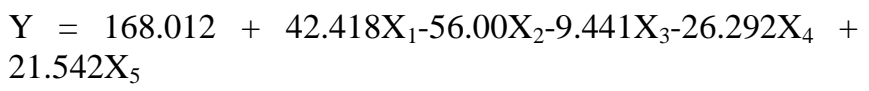

From the above equation can be explained:

1) Obtained a constant value (a) $Y$ of 168,012 , meaning that the financial performance of BMT in Pontianak is 0.692 units, if assumed 1 there is no variable relevance of financial statements, reliability of financial statements, financial statements that can be compared, consistency of financial statements and understandable financial statements (equal to zero).

2) Regression coefficient value for variable $X_{1}$ is 42.418 , it means if the relevance of financial statements increased by 1 unit with assumption variable reliability of financial statements, financial statements that can be compared, consistency of financial statements and financial statements that can understand fixed value, then the financial performance BMT in Pontianak City will experience an increase / increase of 42,418 units.

3) The value of regression coefficient for variable $X_{2}$ is 56.000 , meaning that if the reliability of financial statements increased by 1 unit with the assumption variable relevance of financial statements, financial statements that can be compared, consistency of financial statements and financial statements that can understand fixed value, financial BMT in the city of Pontianak will decrease by 56,000 units.

4) The value of regression coefficient for $X_{3}$ variable is 9.441 , it means that if the financial statements can be compared by 1 unit with assumption variable of relevance of financial report, reliability of financial report, consistency of financial statement and financial statement that can be understood fixed value, financial BMT in the city of Pontianak will decrease by 9,441 units.

5) The value of regression coefficient for variable $X_{4}$ is 26.292, meaning that if consistency of financial statements increase by 1 unit with assumption variable relevance of financial statement, reliability of financial report, financial report which can be compared, and financial statement which can be understood fixed value, hence the financial performance of BMT in Pontianak City will decrease by 26.292 units.

6) The value of regression coefficient for variable $X_{5}$ is 21,542 , meaning that if the financial statement can be understood to increase by 1 unit with assumption variable relevance of financial report, reliability of financial report, financial statements that can be compare and consistency of financial report fixed value, hence financial performance of BMT in Pontianak City will experience an increase of 21,542 units.

\section{Conclusions and Recommendations}

\subsection{Conclusion}

Based on the results of data analysis by verification and research discussion results, it can be drawn conclusion as follows:

1) Of the five quality accounting information examined it can be concluded that a) the relevance of financial statements is "Good"; b) the reliability of financial statements is "good enough"; c) comparable financial statements are "good enough"; d) the consistency of financial statements is "good"; e) understandable financial statements are "good enough".

2) The financial performance of capital structure that is the ratio of capital to voluntary savings (Y1.1) obtained an average of $48.62 \%$ belonging to "Good" productive assets ratio total (Y1.2) of $24.96 \%$ belonging to "Bad", assets the second earning ratio ratio of receivables to non-performing financing (Y.1.3) $24.84 \%$ is classified as "Moderate". The ability of BMT liquidity in Pontianak (Y1.4) is 69.69\% is "Good Enough". Furthermore, the efficiency of operational cost ratio to operating income (Y1.5) is $72.65 \%$ classified as less efficient, while the ratio of investment value to total capital (Y1.6) of $45.30 \%$ is classified as less efficient. Regarding the profitability ratio to the capital ratio (Y1.7) of 5.97\% is moderate. Similarly, the profitability (Y1.8) of $11.87 \%$ is classified Medium.

3) Influence partially (individual) to obtain the value that can be known variables that have the most dominant influence on financial performance BMT in Pontianak City. The variable that has dominant influence is "The financial report that can be understood" because based on regression analysis obtained $\mathrm{t}$ value is the highest when compared with other variables.

4) The linear regression line equation consists of:

a) When assumed 1 there is no variable relavance financial statements, the reliability of financial statements of comparable financial statements, consistency of financial statements and financial statements that can be understood (equal to zero).

b) For variable $\mathrm{X}_{1}$ of 42.418 , then the performance of BMT financial statements in the city of Pontianak will experience an increase of 42,418 .

c) Regression coefficient value for variable $\mathrm{X}_{2}$ equal to $-56,000$ means that if the affirmation of financial report increase 1 with assumption of fixed variable hence performance of financial report of BMT will decrease because of negative sign equal to 56.000.

5) If the $X_{3}$ variable is -9.441 , then the performance of BMT financial report performance decreased because negativ equal to 9,441 .

6) If the value of variable $X_{4}$ is -26.292 , then the performance of BMT financial statements in experiencing penliman because of negative sign of 26.292.

7) f. For the $X_{5}$ variable of 21,542 . then the performance of BMT financial statements in the city of Pontianak increased or increased by 21,542.

\subsection{Recommendations}

1) To improve the quality of accounting information (financial statements BMT) researchers advise the leadership of BMT to improve the return of Human Resources (HR) it. 


\section{International Journal of Science and Research (IJSR) \\ ISSN (Online): 2319-7064}

Index Copernicus Value (2016): 79.57 | Impact Factor (2015): 6.391

2) To improve the performance of BMT given (Y1.2) of $24.96 \%$ classified as having Bad category.

3) To add a broader generation of results it is advisable to increase the object of research in BMT throughout the province of West Kalimantan (Kal-Bar), or all provinces in Indonesia and examine other factors as revealed by researchers there are still $24.40 \%$ other factors not investigated in this researcher.

4) For the government together with IAI and DSN to create financial accounting standard (SAK) for micro sharia business especially BMT in order to become clear base or basis, to improve quality of BMT accounting information going forward.

5) Multiple regression model in this study proved there are variables indevenden $\mathrm{X}$ regression coefficient value which marked negative that is $\mathrm{X}_{2}, \mathrm{X}_{3}$, and $\mathrm{X}_{4}$. researchers suggest to conduct research for researchers again next.

\section{References}

[1] Abdul Majid, Baihaqi et al. 2000. New Paradigm of Democratic Economy of Sharia System: Journey of Ideas and Movement of BMT in Indonesia, Printed 1: Publisher PINBUK, Jakarta.

[2] Accounting and Auditing Organization for Islamic Financial Institution. 1998. Accounting and Auditing Standards for Islamic Financial Institution, Statement of Financial Accounting, No.2, Bahrain.

[3] Adiwarman Karim. 2003. Islamic Bank: Fiqh and Kuangan Analysis, Publisher of The International Institute of Islamist Thought Indonesia, Jakarta.

[4] A.Djazuli, and Yadi Yanwari. 2002. People's Economic Institutions: An Introduction, Publisher PT Raja Grafindo Persada, Jakarta.

[5] A.M. Saefuddin. 1987. Economics and Society In The Perception of Islam, Publisher Rajawali, Jakarta

[6] Anthony, Robert N., David D. Hawkens and Keneth A. Marchant. 1999. Accounting Text and Cases, Tenth. Ed., Irwin-MC. Graw-Hill, Singapore.

[7] Arikunto, Suharsimi. 1998. Research Procedure, Rineka Cipta, Jakarta.

[8] Bambang Riyanto. 2001. Company Learning Basics, Fourth Edition, Cet. to 7, BPFE UGM, Yogyakarta.

[9] Belkaouni and Ahmad Raihi. 2000. Accounting Theory, Fourth Edition, Merwata.dkk Translation, Volume I, Publisher Salemba Four, Jakarta.

[10] Cooper, W.W and Yuji Ijril. 1984. Kohler's Dictionary for Accountants, 6th Edition, Printice Hall of Coporate Limited.

[11] Dajan, Anto. 2000. Introduction to Statistical Methods, Volume I, Pustaka LP3ES Indonesia, Jakarta.

[12] De Alwis, Shrianjani Marie (Gina) and Susan Ellen Higgins. 2001. Information as a Tool for Management Decision Making: a Case Study of Singapore, Information Research, No.7.1, October.

[13] D Hartanto, 1981, Accounting for Entrepreneurs, Institute of Publishers Faculty of Economics, University of Indonesia, Jakarta.

[14] Endang Saifuddin Anshori. 1990. Islamic Insight: The Principles of Thoughts on Islam and Its People, CV. Rajawali, Jakarta.

[15] Financial Accounting Standardsd Board. 1981. Financial Accounting Standards: Original
Pronouncements, Statement of Financial Accounting Concepts No.2, Connecticut.

[16] Ghazali, Imam. 2007. Application of Multivariate Analysis with SPSS program, Diponogoro University Publishing Agency, Semarang.

[17] Heri Sudarsono. 2003. Bank and Sharia Financial Institution, Description and Illustration, Econasia Publishers, Yogyakarta.

[18] Hines, Ruth D. 1989. The Sociopolitical Paradigm in Financial Accounting Research, Accounting, Auditing and Accountability Journal 2 (1).

[19] H.M.Omer Chapra. 2001. The Future of Economics: Islamic Perspective, Publisher SEBI, Jakarta.

[20] Indonesian Accounting Association. 2009. Basic Framework for Preparation and Presentation of Sharia Financial Statements, Publisher Salemba Empat, Jakarta.

[21] -------------. 2009. Statement of Financial Accounting Standards No.59 Accounting for Syariah Banking, Publisher Salemba Four, Jakarta.

[22] ---------------. 2009. Financial Accounting Standards, Publisher Salemba Four, Jakarta.

[23] Iwan Triyowono. 1996. Accounting Theory Faced with Islamic Values, Ulumul Qur'an, Vol. IV No.5, Pg. 44.

[24] ---------. 2003. SFAS 59: Individualistic and Capitalistic, Article 5 Capital Year

[25] Kastin Hasan. Surtahman. 1990, Islamic Economics, Publisher University Kebangsaan Malaysia, Bangi Malaysia.

[26] Kieso, Donald E, Jerry J. Weygandt and Terry D. Warfield. 2004. Intermediate Accounting, Eleventh Edition, John Wiley \& Sond, Inc., USA.

[27] Muhammad Daud Ali. 1996. Islamic Economic System: Zakat and Endowments, Publisher University of Indonesia, Jakarta.

[28] Mahmudi. 2001. Earnings Management: An Overview of Accounting Ethics, Journal of Business and Accounting, Vol.3, No..2, August, Page 395.

[29] Muhammad. 2002. Introduction to Sharia Accounting, Publisher Slemba Empat, Jakarta.

[30] Mulyadi, 1993, Management Accounting: Concepts, Benefits and Engineering, Second Edition BPSTIE YKPN, Yogyakarta.

[31] Small Business Incubation Center. 2000. Health Level of BMT, Jakarta.

[32] ----------, Without Year, Guidance on How to Establish BMT, Jakarta.

[33] Qardawi, Yusuf, Translation. 1997. Normal and Islamic Economic Ethics, Publisher Gema Insani Press, Jakarta.

[34] Rifaat Ahmed Abdul Karim. 1999. Accounting in Islamic Finacial Institutions, Accounting and Bisness, July / August, p.32.

[35] Sefuddin Azwar. 1997. Reability and Validity, 3rd Edition, Publisher Pustaka Pelajar, Yogyakarta.

[36] Santoso, Singgih. 2005. Mastering Statistics in the Information Age with SPSS, Graha Ilmu, Yogyakarta.

[37] Sudarmanto. 2005. Multiple Linear Regression Analysis with SPSS, Graha Ilmu, Yogyakarta.

[38] Sugiyono. 2004. Business Research Methods, Alfabeta, Bandung.

[39] Sugiyono. 2004. Statistics for Research, Alfabeta, Bandung. 


\section{International Journal of Science and Research (IJSR) \\ ISSN (Online): 2319-7064}

Index Copernicus Value (2016): 79.57 | Impact Factor (2015): 6.391

[40] Syahata, Hussein. 2001. Principles of Islamic Accounting Thoughts, Translation by Khusnul Ftarib, Akbar Publishers, Jakarta.

[41] Van Horne, James C. 2000. Financial Management and Policy, Twelfth Edition, Printice-Hall, Inc., New Jersey.

[42] Widayat and Amirullah. 2002. Business Research, Graha Ilmu, Yogyakarta.

[43] Yasni M, G. 2003. Sharia Investment: Little Wong, Articles Magazine

\section{Author Profile}

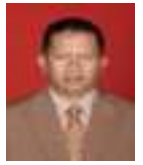

Dr. Muhammad Syaifullah, SE.,M.Si, Is Lecturer at the Faculty of Sharia and Islamic Economics, Pontianak Institute of Islamic Studies. Paper:(1) "The Role of Environmental Uncertainty, Organizational Structure, and Information Technology, Towards SIAM Characteristics Impacts on Managerial Performance", IJEB, April 2013;(2) "The Role of Government Accounting in Managing Regional Financial Accountability", JRAB, FE UniversitasMuhammadiyah Sumatera Utara, March 2011; (3) "Quality Accounting Information System", JRAB, FE University of Muhammadiyah, North Sumatera, September 2010; (4) "Influence Organizational Commitment On The Quality Of Accounting Information System", IJSTR, September 2014; (5) "Influence Business Process On The Quality Of Accounting Information System ", IJSTR, January 2015; (6) "Understanding of Village Apparatus on Implementation Accounting Villages, International Journal of Science and Research (IJSR), Vol. 6 Issue 8, August 2017; (7) "Influence Of Information Technology On Quality Of Accounting Information System", IJSR, Volume 6, Issue 11, November 2017; (8)"The Influence Of Organization Culture On Quality Of Implementation Of Accounting Information System", IJRASET, Volume 5, Issue X1, November 2017; (9)"The Influence Of Frontliner Service Quality On Customer Satisfaction at BNI Syariah", IJIRMF, Volume-3, Issue-11, Nov-2017; (10)"Influence of Organization Structure onQuality of Accounting Information System", Imperial Journal of Interdisciplinary Research (IJIR), Vol-3, Issue-12, Dec-2017; (11)"The Influence Of Top Management Commitment and Organizational Culture On Implementation Of Management Accounting Information System (A Study At People's Credit Banks (BPR) In Pontianak City), Indonesia". (IJIR), Vol. V, Issue 12, December 2017.

Book: (1)" Management Accounting Information System, 2012, STAIN Pontianak Press; (2) The Fasting of the Universe, First Printing, November 2016, IAIN Pontianak Press; (3)“"Quality of Customer Service at Bank Negara Indonesia (BNI) Syariah, First Printing, August 2017, IAIN Pontianak Press; (4) Editor: "Inland Social Economic",IAIN Pontianak Press, Sep-2015. Lecturer: (1) STAIN/IAIN Pontianak; Pontianak State Polytechnic; (2) STIEP Pontianak; (3) Indonesian Computer Education Institute (LPKIA) Pontianak; (4) Langlangbuana University Bandung; Mercubuana University Jakarta; (5) Widyatama University Bandung; (6) STIE Equity Bandung; Bandung Practitioner Polytechnic; (7) UNICOM Bandung. Audit experience:(1) Tax Audit PT. BPR Utama Kita Mandiri (Chairman of TEAM Audit); (2) Audit Taxation PT. BPR ARIDHA ARTA NUGRAHA, (Chairman of the Audit Team); (3) General Audit on the Financial Report of Prosperous Employees Cooperative PTPN XIII Kalbar.

Volume 6 Issue 12, December 2017 www.ijsr.net 